\title{
THE EQUIVALENCE IN TRANSLATION OF PUJA TRI SANDHYA FROM INDONESIAN TO ENGLISH
}

\author{
Anak Agung Inten Mayuni \\ Universitas Warmadewa \\ intenmayuni59@gmail.com
}

\begin{abstract}
ABSTRAK
Puja Tri Sandhya is Hindus prayer known in all countries. The original prayer came in Sanskrit language, but every Hindus believer already translate the prayer into their native language. In 1950, Balinese Hindus used Puja Tri Sandhya to get the recognition from the government allowing Parisada Hindu Dharma Indonesia (PHDI) - the major reform movement and Hindus organization in Indonesia - to translate Puja Tri Sandhya into Indonesian. This translation aimed to make every Hindus believer in Indonesia knows about the meaning of the mantras. Besides Indonesian, Puja Tri Sandhya is also translated into the universal language that 20 percent of the world spoke, English. English is believed to give the best medium to other people who want to learn more about Hindus or simply just curious. As a reminder, in this paper Indonesian will be the source language (SL) and English will be the result of the translation so we shall call it target language (TL). In translation, equivalency will be the point to show if the translation is well translated or not. In their book The Theory and Practice of Translation (1959), Nida and Taber state two kinds of equivalency that the translator can use as their reference they are: formal and dynamic equivalence. Here, Puja Tri Sandhya in Indonesian and English versions will be analyzed using 2 kinds of equivalences by Nida and Taber.
\end{abstract}

Keywords: Balinese Hindus; equivalence; Puja Tri Sandhya; translation

\section{INTRODUCTION}

Translation is the nature of language deliverance. Every language can be translated into other languages with literal meaning that can be found in the dictionary or using the experience of nature and social approaches. Jakobson statesin his paper there are 3 kinds of translation; Intralingual translation, Interlingual translation and Intersemiotic translation (transmutation) (Jakobson, 1959).

Intralingual translation or rewording is the process of translation when the verbal signs are interpreted into other signs in the exact same language, Interlingual translation (translation proper) is the process of translation when the verbal signs of one language interpreted into another language and intersemiotic translation (transmutation) is the process of translation when the verbal signs interpreted into nonverbal signs.

In the process of translating the translators need to make the target language (TL) has the whole meaning from the source language (TL).
This process of translation might vary, for instance: changing the words literally, restructuring the grammatical form of the SL, and change the words based on the nature and social approaches of the TL. Nida defines that there are two kinds of equivalence in translation; Formal equivalence focused to the form and content of the message and the meaning in the receptor language (TL) should be as close as possible with the SL. The second is Dynamic or functional equivalence focused to the grammar, lexicon, and cultural reference, dynamic equivalence has a goal to make the message in the TL is as natural as possible (Nida, 1964 : 159).

While Nida's analysis is focused in translation of Bible verse from Latin to English, in this paper the translation that will be analysed is Puja Tri Sandhya which is well known world-wide as Balinese Hindus everyday prayer. Puja Tri Sandhya originally comes from Indian Sanskrit mantras which is standardized in Bali. Puja Tri Sandhya was developed in 
1950, when in that time, Balinese Hinduism needs recognition to be qualified as one of the modern Indonesian state religion. Hynson states that the mantra is sung in Old-Javanese (Kawi) language commonly heard at temple celebrations and anniversaries. Puja Tri Sandhya itself already translated into some different languages to make the mantras understood easily by Hindus people who spoke different language than Indonesian since this prayer is commonly used in Indonesia. English is one of the language that Puja Tri Sandhya is translated into. In this paper, I will analyse the equivalence of Indonesian-English translation in Puja Tri Sandhya.

This paper will use Nida's theory of equivalence to find out about whether the Indonesian-English translation of Puja Tri Sandhya is classified into formal or dynamic equivalence.

\section{METHOD}

Each language has its own genius and each language possesses certain distinctive characteristic which give it a special character (Nida \& Taber, 1982: 3) Every language has some distinctive speakers or socioeducational levels of speech and comprehension (Nida \& Taber, 1982) and those levels of speech can affect how someone will accept the message they read or heard.

English is one of the languages that spoke internationally by million people. Almost - but not all-subjects are translated into English. English becomes most medium used to imply many subjects, such as: medical, education, economy, and even prayer. Besides being the target language (TL) in translation, English also becomes the language that mostly being translated into another languages. People usually works in English (either spoke, wrote or both) to make their target reader understood. However, not all the reader or listener spoke native English, therefore to hold more target readers or listener, translators came to save the day by translating many written subjects into other languages needed by the target readers.

Translation can be found in any forms, verbal or nonverbal symbols. In 1959, Jakobson states that there are three types of translation:

1. Intralingual translation or rewording is an interpretation of verbal signs by means of other signs of the same language. (Jakobson, 1959: 233).

2. Interlingual translation or translation proper is an interpretation of verbal signs by means of some other language. (Jakobson, 1959: 233).

3. Intersemiotic translation or transmutation is an interpretation of verbal signs by means of signs of nonverbal sign systems. (Jakobson, 1959: 233).

Jakobson also defines translation involves two equivalent messages in two different codes (1959: 233). Based on that statement, we can define that translation between two languages, whether its verbal or nonverbal should be equivalence which means the message carried in SL supposed to be similar with the message in TL. Despites, in Jakobson's discussion, the problem of meaning and equivalence differences in the structure and terminology of languages rather than on any inability of one language to render a message that has been written in another verbal language (Munday, 2001: 37-38). Nevertheless, to reach the equivalency in translation, there are four basic requirements of translation stated by Nida, they are:

1. Making sense

2. Conveying the spirit and manner of the original

3. Having a natural and easy form of expression

4. Producing a similar response

Munday in his book Introducing Translation Studies (2001: 40) cites Nida statements that there are two kinds of equivalence can be found in translation:

1. Formal equivalence

Formal equivalence focuses attention on the message itself, in both form and content...One is concerned that the message in the receptor language should match as closely as possible the different elements in the source language (Nida, 1964b).

2. Dynamic equivalence

Dynamic or functional equivalence is based on what Nida calls 'the principle of equivalent effect', where 'the relationship between receptor and message should be substantially the same as that which 
existed between the original receptors and the message' (Nida, 1964a: 159).

Formal equivalence also called gloss translation because the source language's structure and meaning supposed to be really close with the grammatical form and culture of the target language. On the other hand, dynamic equivalence relays on the target's linguistic knowledge and cultural expectation. Nida and Taber states that 'naturalness' is a key requirement in translation hence Nida defines that making the closest and equivalent translation is the main goal of dynamic equivalence

If we bear in mind, the second equivalence stated by Nida is focused to the grammar, lexicon, and cultural reference. It means, dynamic translation got a process of restructuring the grammar from the SL to the TL. (Nida \& Taber, 1969: 33) defines about three-stage system of translation which includes analysis, transfer and restructuring. Below, Nida makes two figures of grammatical analysis:

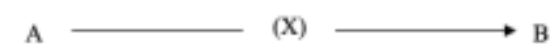

Figure 1

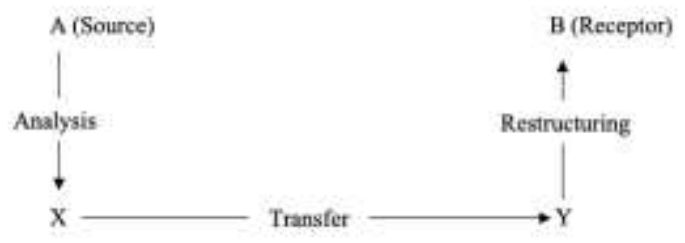

Figure 2

Figure 1 exemplifies the literal translation which is transferring the message from source language to target language based on the cultural expectation of the TL. Meanwhile figure 2 represents the whole changing translation where the translators have to do an analysis of the meaning from the source language (SL), transfers it and restructuring the grammar, lexicon, and the nature reference to make the closest meaning possible in TL compared to the SL.

In this paper, the subject that would be identified and analyzed is Puja Tri Sandhya. Puja Tri Sandhya is originally compiled from Indian Sanskrit mantras standardized in Bali. This prayer performed as a daily prayer. Puja Tri Sandhya is written in many languages to approach its believers who comes from many countries. Besides Indonesian, English is one of the languages which is the prayer translated into. Besides that, Parisada Hindu Dharma Indonesia (PHDI) - the major reform movement and Hindus organization in Indonesia provides the transcript of Puja Tri Sandhya which is already translated from Sanskrit to Indonesia and English.

Furthermore, this paper will analyze the equivalency of Puja Tri Sandhya in Indonesian to English using the theory of translation by Jakobson and theory of equivalency by Nida and Taber.

\section{DISCUSSION}

This chapter will show the analysis of equivalency Puja Tri Sandhya's translation from Indonesian to English taken from standardized version of Puja Tri Sandhya by PHDI.

Puja Tri Sandhya has 6 verses and each verse is praising Gods. Hindus is well known world-wide believe in many names of God. As the disclaimer, the standardized translation from PHDI are not changing all the name of the Gods, for instance: Om, Sanghyang Widhi, Narayana, Siva, Mahadeva, Isvara, Paramesvara, Brahma, Visnu, Rudra, and Purusa. So that, there will be no analysis done for verse 3 since the verse is not translated into Indonesian. Some terms in Sanskrit language also not translated, such as; bhur, bhuvah, svah which presents three worlds in Hindus. Besides of that, every words and sentences have been translated from Sanskrit to Indonesian and from Indonesian to English.

Based on the analysis using the Jakobson theory of translation, Puja Tri Sandhya is the part of interlingual translation since the SL is translated into different language both the words and the structures.

Table below provides complete Puja Tri Sandhya verses in Indonesian which is considered as the source language (SL) and English which is considered as the target language (TL).

\begin{tabular}{|c|l|l|}
\hline Verse & $\begin{array}{c}\text { Indonesian } \\
\text { Translation (SL) }\end{array}$ & $\begin{array}{c}\text { English } \\
\text { Translation (TL) }\end{array}$ \\
\hline Verse & $\begin{array}{l}\text { Om adalah } \text { bhur } \\
\text { bhuvah svah. Kita } \\
\text { memusatkan }\end{array}$ & $\begin{array}{l}\text { Om is bhur, } \\
\text { bhuvah and svah. } \\
\text { Let us meditate on }\end{array}$ \\
\hline
\end{tabular}




\begin{tabular}{|c|c|c|}
\hline & $\begin{array}{l}\text { pikiran pada } \\
\text { kecemerlangan } \\
\text { dan kemulian } \\
\text { Sanghyang } \\
\text { Widhi }^{1 \text { (verse 1) }} \text {, } \\
\text { semoga Ia berikan } \\
\text { semangat pikiran } \\
\text { kita. }^{2 \text { (verse 1) }}\end{array}$ & $\begin{array}{l}\text { the light and glory } \\
\text { of Sanghyang } \\
\text { Widhil(verse 1), and } \\
\text { may He give us } \\
\text { spirit to our } \\
\text { thoughts! }{ }^{2(\text { verse } 1)}\end{array}$ \\
\hline $\begin{array}{c}\text { Verse } \\
2\end{array}$ & $\begin{array}{l}\text { Om Narayana } \\
\text { adalah semua ini } \\
\text { apa yang telah ada } \\
\text { dan apa yang akan } \\
\text { ada } 1 \text { (verse } 2 \text { ), bebas } \\
\text { dari noda, bebas } \\
\text { dari kotoran, } \\
\text { bebas dari } \\
\text { perubahan tak } \\
\text { dapat } \\
\text { digambarkan }{ }^{2} \text { (verse } \\
\text { 2), sucilah dewa } \\
\text { Narayana, Ia } \\
\text { hanya satu tidak } \\
\text { ada yang kedua. } \\
\text { (verse 2) }\end{array}$ & $\begin{array}{l}\text { Om, Narayana is } \\
\text { this entire } \\
\text { universe, what has } \\
\text { been and what } \\
\text { will be }{ }^{1 \text { (verse } 2)} \text {; } \\
\text { free from taint, } \\
\text { free from dirt, free } \\
\text { from mental } \\
\text { constructs and } \\
\text { free from } \\
\text { appellation }{ }^{2(v e r s e ~} 2 \text { ); } \\
\text { He is Narayana, } \\
\text { the pure God: He } \\
\text { is only one and } \\
\text { there is no other. }{ }^{3} \\
\text { (verse } 2 \text { ) }\end{array}$ \\
\hline $\begin{array}{c}\text { Verse } \\
3\end{array}$ & $\begin{array}{l}\text { Om Engkau } \\
\text { dipanggil Siva, } \\
\text { Mahadeva, } \\
\text { Isvara, } \\
\text { Paramesvara, } \\
\text { Brahma, Visnu, } \\
\text { Rudra dan } \\
\text { Purusa. }\end{array}$ & $\begin{array}{l}\text { Om, you are } \\
\text { called Siva, } \\
\text { Mahadeva, Isvara, } \\
\text { Paramesvara, } \\
\text { Brahma, Visnu, } \\
\text { Rudra, and } \\
\text { Purusa. }\end{array}$ \\
\hline $\begin{array}{c}\text { Verse } \\
4\end{array}$ & 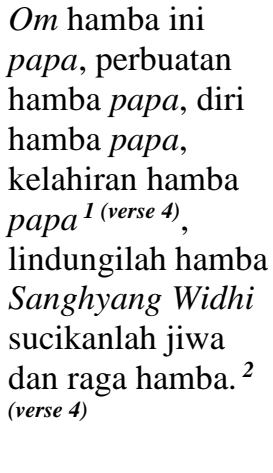 & 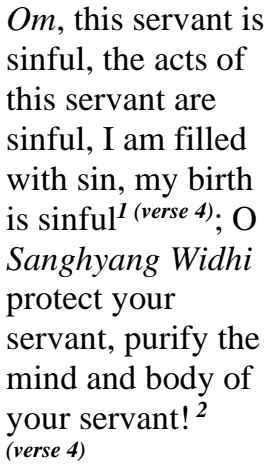 \\
\hline $\begin{array}{c}\text { Verse } \\
5\end{array}$ & $\begin{array}{l}\text { Om ampunilah } \\
\text { hamba Sanghyang } \\
\text { Widhi, yang } \\
\text { memberikan } \\
\text { keselamatan } \\
\text { kepada semua } \\
\text { makhluk }{ }^{\text {(verse 5), }} \\
\text { bebaskanlah } \\
\text { hamba dari segala } \\
\text { dosa, lindungilah } \\
\text { oh Sang Hyang } \\
\text { Widhi. } \\
\text { 2(verse 5) }\end{array}$ & $\begin{array}{l}\text { Om, forgive me } \\
\text { Sanghyang Widhi, } \\
\text { who give } \\
\text { salvation to all } \\
\text { sentient beings! }^{1} \\
\text { (verse 5) Save me } \\
\text { from all this } \\
\text { sorrow, guide me, } \\
\text { redeem and } \\
\text { protect me, O } \\
\text { Sang Hyang } \\
\text { Widhi! } \\
2 \text { (verse 5) }\end{array}$ \\
\hline
\end{tabular}

\begin{tabular}{|c|c|c|}
\hline $\begin{array}{c}\text { Verse } \\
6\end{array}$ & $\begin{array}{l}\text { Om ampunilah } \\
\text { dosa anggota } \\
\text { badan hamba, } \\
\text { ampunilah dosa } \\
\text { perkataan hamba, } \\
\text { ampunilah dosa } \\
\text { pikiran hamba, } \\
\text { ampunilah hamba } \\
\text { dari kelalaian } \\
\text { hamba. }{ }^{1 \text { (verse 6) }} \\
\text { Om damai, damai, } \\
\text { damai, Om. }{ }^{2 \text { (verse }} \\
\text { 6) }\end{array}$ & $\begin{array}{l}\text { Om, forgive my } \\
\text { sinful deeds, } \\
\text { forgive my wrong } \\
\text { speech, forgive } \\
\text { my sinful mind, } \\
\text { forgive me for all } \\
\text { those misdeeds } \\
\text { and birth! } 1 \text { (verse 6) } \\
\text { Om, [may there } \\
\text { be] peace, peace, } \\
\text { peace, Om. }{ }^{2 \text { (verse 6) }}\end{array}$ \\
\hline
\end{tabular}

(Lanus, 2015: 254)

In the verse 1, SL 1 (verse 1) is translated into TL 1 (verse 1) are supposed to be translated literally in to focus, yet it translated into meditate. Balinese Hindus use a certain position in doing prayer called Padmasana and the term of managing our breath called Pranayama. Hindus prayers use meditating as their way to pray. Shastri (1950: 7) states that meditating means the moments of silence and focused the mind from any places. You are not allowed to think about your friends, mother, father and $e t$ cetera. After that, close your eyes for one minute and do the Pranayama. The translators chose to use meditate rather than focused after processing the message in TL using the culture reference approach. Meditate is considered to give the closest message in the culture of Balinese Hindus in TL than focus. As the theory states by Nida, this translation is the part of dynamic equivalence and used the figure 2 where the source language needs to be reformulated to the closest meaning and structure of the target language.

In the second line, SL 2 (verse 1) is translated into TL 2 (verse 1). Analytically, there is no words change into another form, yet the structure is. While literally 'Ia berikan semangat pikiran kita' supposed to be translated to 'He gives our thoughts a spirit' the translators chose to translate it using passive form into 'He give us spirit to our thoughts!'. This translation aimed to transfer a clearer message in target language about what the God gave to their believers. As the theory states by Nida, this translation is the part of dynamic equivalence and used the figure 1.

Therefore, we can state that verse 1 in Puja Tri Sandhya is the part of dynamic equivalence 
and using the combination of both figure 1 and figure 2 in their grammatical approaches.

In the verse 2, SL 1 (verse 2) is translated into TL 1 (verse 2). In this case, the $\mathrm{SL}$ is not giving a clear message about what is the line talked about. By just saying apa yang telah ada dan apa yang akan ada it will be translated into what is here and what it will be, not mentioning anything. If we seek on the history of Hindus, this religion believes that everything comes from universe and back to the universe. The translator clearly restructuring the line based on the history of the religion and make the message clearer, then we understand about what is the line aimed to and mean in the $\mathrm{TL}$, this translation is the part of dynamic equivalence and used the figure $\mathbf{2}$ where the source language needs to be reformulated to the closest meaning and structure of the target language.

In the second line, SL 2 (verse 2) is translated into TL 2 (verse 2). Here, translator translated the line literally to the target language, although, the line bebas dari perubahan tak dapat digambarkan which is supposed to be translated into free from the undefined changing is not translated literally to the TL. The line before is translated into free from mental constructs and free from appellation. This translation has a unique restructuring, since the literal meaning would be contradictory with the result of translation. Mental construct means simply the set of ideas and beliefs that we hold (https://medium.com/@ richardragnarson/ment al-constructs-the-cornerstone-of-self-

improvement-4708b1b20b98) and appellation means an identifying name or title (https://www.merriam-

webster.com/dictionary/appellation). The restructuring process in this translation needs a logically thinking based on the nature of the language and the religion itself. Logically, everybody has mind to think and produce thought, it can change dynamically without other people knowing. Along with appellation, someone can be identified into many names and citations based on their education, social life, or family, and the names can change anytime due to many circumstances. After taking a look on the logical thinking before, we can say that names and thoughts are changing times to times and cannot be defined, therefore, undefined changing is equivalent with mental constructs and appellation based on the context of the line. As the theory states by Nida, this translation is the part of dynamic equivalence and used the figure 2 where the source language needs to be reformulated to the closest meaning and structure of the target language.

The last line of verse 2, SL 3 (verse 2) is translated into TL 3 (verse 2). Based on the translation above, the translator changed nothing but the grammatical structure of the line. Sucilah dewa Narayana translated into $\mathrm{He}$ is Narayana, the pure God to make the target language got the closest meaning that Narayana is the God and He is pure. As the theory states by Nida, this translation is the part of dynamic equivalence and used the figure 1.

Therefore, we can state that verse 2 in Puja Tri Sandhya is the part of dynamic equivalence and using the combination of both figure 1 and figure 2 in their grammatical approaches.

In the verse 4, SL 1 (verse 4) is translated into TL 1 (verse 4). The equivalency in this translation is questioned since the PHDI's standardized version also did not translate the word papa into the equivalent language. However, Shastri in his book wrote hambaMu penuh dosa, perbuatan hambaMu adalah penuh dosa-dosa dan budi hambaMu adalah jahat semenjak lahir as the translation of the verse 4 in Puja Tri Sandhya. Moreover, in Sanskrit glossary online, $P \bar{a} p \bar{a}$ means kinds of sins

(https://www.wisdomlib.org/definition/papa)(S hastri, 1950). This translation is the part of dynamic equivalence and used the figure 2 since it changes the word from the Indonesian source into the literal meaning of Papa so that every Hindus believer around the world would get the literal meaning that they can understand rather than a banal meaning of Papa.

In the second line, SL 2 (verse 4) is translated into TL 2 (verse 4). As we see, this translation did not change any structure of the line as while all the words changed literally into English. As the theory states by Nida, this translation is the part of dynamic equivalence and used the figure 1.

Therefore, we can state that verse 4 in Puja Tri Sandhya is the part of dynamic equivalence 
and using the combination of both figure 1 and figure 2 in their grammatical approaches.

In the verse 5, SL 1 (verse 5) is translated into TL 1 (verse 5). This line has the word hamba as the verse 4 has, but it is translated differently, while in the verse 4 hamba is translated into servant but in the verse 5 it is translated into me. If we think logically, we as a human who believe in God is basically his servant. We do what He told us and we believe on his presence. Hence, me and servant has an equivalency in the nature of meaning. Besides that, all the line from SL was translated literally into TL without changing the structure nor the nature of meaning. As the theory states by Nida, this translation is the part of dynamic equivalence and used the figure 1.

In the second line, SL 2 (verse 5) is translated into TL 2 (verse 5). The structure of translation changed due to get more complete meaning in the target language. The line guide me, redeem and protect me is used to give additional meaning to the translation and make it became more understandable. As the theory states by Nida, this translation is the part of dynamic equivalence and used the figure 1 where the source language only needs to change the structure of the sentence and give additional line to make it more understandable.

Therefore, we can state that verse 5 in Puja Tri Sandhya is the part of dynamic equivalence and using the figure 1 in their grammatical approaches.

In the verse 6, SL 1 (verse 6) is translated into TL 1 (verse 6). There is one additional word added to the target language, birth. Word birth added to this line to make this line became understandable and gaining more complete meaning. In Hindus, we believe that we already carry sins since we were a new born and it makes the translator added this as an additional adaptation for the target language. Besides that, all the words were translated literally into the target language without changing any structure of the grammar and nature of the language. As the theory states by Nida, this translation is the part of dynamic equivalence and used the figure 1.

In the second line, SL 2 (verse 6) is translated into TL 2 (verse 6). While the translator supposed to translate damai, damai, damai into peace, peace, peace, they added may there be to make the line became more rational. After praying, Hindus will say shanti, shanti, shanti which then translated into damai, damai, damai because all we pray for is goodness for us and might be there is peace in our heart and world. Therefore, the target language added may there be to indicate the hope that we got peace after we have done praying. As the theory states by Nida, this translation is the part of dynamic equivalence and used the figure 1.

Therefore, we can state that verse 6 in Puja Tri Sandhya is the part of dynamic equivalence and using the figure 1 in their grammatical approaches.

\section{CONCLUSION}

This study reveals that Puja Tri Sandhya is already translated equivalently using Nida's theory as the reference. Therefore, all of the verses are the part of dynamic equivalence.

Three out of five verses which are verse 1 , verse 2 and verse 4 are proven using the combination of both grammatical equivalent in its translation, while two other verses which are verse 5 and verse 6 used only figure 1 in its translation.

These figures used to reach the main goal of translation, which transfers the message from the source language to the target language as close as possible. Figure 1 presents that the process of transferring the message from the source language to the target language can be so short and literal, there is no changing in lexicon, grammar, or the nature reference while figure 2 presents that the message transferring process from the source language to the target language sometimes need some kinds of restructuring to make the message in the target language delivered as natural as possible.

\section{REFERENCE}

Eugne. A. Nida \& Charles.R. Taber. (1969). The Theory and Practice of Translation. E.J Brill.

Jakobson, R. (1959). On Linguistic Aspect of Translation On Translation 1.

Munday, J. (2001). Introducing Translation Studies. Routledge.

Nida, E. (1964a). Principles of Correspondence. Translation Studies Reader 9. Routledge.

Nida, E. (1964b). Toward a Science of 
THE EQUIVALENCE IN TRANSLATION OF PUJA TRI SANDHYA ...

Translating. E. J. Brill.

Nida, E., \& Taber, C. (1982). The Theory and

Practice of Translation. United Bible
Societies.

Shastri, N. (1950). Tri-Sandhya. Bhuvana Saraswati. 